\title{
Value Co-Creation in the Sharing Economy Platform: The Role of Ethical Perceptions
}

\author{
Miharni Tjokrosaputro \\ Faculty of Economics and Business, Universitas Tarumanagara, Jakarta, Indonesia \\ Email address: \\ miharnit@fe.untar.ac.id
}

\begin{abstract}
This study aims to determine the effects of consumer participation on value cocreation with consumers' ethical perceptions as a mediation of the sharing economy platform in Indonesia. The research design used a quantitative method with a descriptive approach. The sampling technique used convenience sampling with 287 respondents. A questionnaire was utilized as the data collecting technique. SmartPLS was applied as the analysis tool. The results showed that consumer participation has a significant effect on ethical perceptions and value co-creation and ethical perceptions affect value co-creation significantly. Furthermore, this research proof that ethical perceptions mediate the positive relationship between value co-creation on the sharing economy platform in Indonesia. This research enrich and strengthen the role of consumer ethical perceptions and consumer participation in creating value co-creation that provides value for both consumers and service providers based on Service-Dominant Logic (Vargo and Lusch, 2008).
\end{abstract}

Keywords: value co-creation, ethical perceptions, consumer participation, sharing economy platform.

\begin{abstract}
Abstrak: Penelitian ini bertujuan untuk mengetahui pengaruh Partisipasi Konsumen Pada Nilai Kreasi Bersama (Value Co-creation) Dengan Persepsi Etis Konsumen Sebagai Mediasi Pada platform berbagi ekonomi (Sharing economy platform) di Indonesia. Desain penelitian ini menggunakan metode kuantitatif dengan pendekatan deskriptif. Teknik pengambilan sampel menggunakan convenience sampling, dengan 287 responden. Teknik pengambilan data dengan menggunakan kuesioner. Alat analisis yang digunakan adalah SmartPLS. Hasil penelitian menunjukkan bahwa Partisipasi Konsumen berpengaruh secara signifikan terhadap Persepsi Etika dan Nilai kreasi bersama, Persepsi Etika berpengaruh terhadap Nilai Kreasi Bersama dan Persepsi etika memediasi hubungan antara partisipasi Nilai Kreasi Bersama secara positif pada platform berbagi ekonomi di Indonesia. Penelitian ini memperkaya dan memperkuat peran persepsi etis konsumen dan partisipasi konsumen dalam menciptakan nilai Kreasi Bersama yang memberikan nilai bagi konsumen dan penyedia layanan berdasarkan Service-Dominant Logic (Vargo dan Lusch, 2008).
\end{abstract}

Kata Kunci: nilai kreasi bersama, persepsi etis, partisipasi konsumen, platform berbagi ekonomi. 


\section{INTRODUCTION}

In this decade, the sharing economy or sharing economy platform (hereinafter abbreviated as SEP) has become an interesting phenomenon with a very rapid development. Many people use vacant private property to share with others so that both parties benefit in achieving their respective goals. As summarized from several articles from statista.com, the popularity of SEP use in the world has increased rapidly in this decade, where in 2015 the value of SEP use was USD 15 billion and in 2025 it is estimated that it will reach a value of USD 335 billion (statista.com, 4 Nov 2020). In addition, Indonesia is the highest SEP user country with a value of USD five billion in ASEAN (Moore, 2020) with the number of SEP users in Indonesia reaching 21.7 million people in early 2020 (Astutik, 2020).

The development of the use of SEP in the world is quite rapid with various uses, including for transportation, food delivery, shopping, delivery of goods, and so on. Many people prefer the use of SEP over the use of conventional taxis because of lower costs and shorter waiting times. At the beginning of the COVID-19 pandemic, the use of SEP had decreased by $65 \%$ due to social distancing and various regulations made by the government (Mazareanu, 2020), but these conditions are gradually improving and it is predicted that the use of SEP in the world will increase by more than 50 percent in 2021 (Wagner, 2020).

As the country with the highest number of SEP users in Southeast Asia (Moore, 2020), Indonesia has two transportation-based SEPs, namely Grab, which is based in Singapore, and Gojek, which is headquartered in Indonesia. Grab has around 2.8 million active ridesharing providers, while Gojek has around 1 million active ride-sharing providers (Moore, 2020). SEP has expanded its business to several countries in the Asia Pacific. In recent years, the growth of Gojek's active users in ASEAN has increased rapidly, so that Gojek has become one of the SEPs to be reckoned with. For this reason, this study uses Gojek user respondents in Indonesia.

In the operation of SEP activities, an application is needed that helps connect service providers and consumers, so that it can facilitate economic activities to be carried out so as to provide value to each party. SEP brings people together to participate and create value through their connections and experiences (Perren and Kozinets, 2018); thus, SEP becomes an important marketing tool. In SEP, the interactions between service providers and consumers are important in conducting business agreements. The role of interactions through SEP is very different from conventional e-commerce platforms, where there are no direct interactions between the seller and the buyer. In other words, the online platform covers the entire ownership transfer process (Mittendorf, 2016). In an online world where buyers and sellers have no experience with each other, online platforms play an important role in increasing consumer trust, so that it can lead to business exchanges (Perren and Kozinets, 2018). SEP is based on the principle of sharing information, and it requires consumers to enter detailed personal information, which is sometimes misused for other commercial purposes (Dillahunt and Malone, 2015).

In safeguarding consumer data, the company also maintains the privacy of consumers who have entrusted their data to the company to be used as wisely as possible in order to provide consumers with the services provided by the company. In addition, companies must be able to provide security guarantees for consumers, so that consumers have a sense of trust in using the services provided. This includes the security offered by the company, which is expected by consumers in providing and receiving services. Privacy and security are 
dimensions of the ethical perceptions variable. Consumers' ethical perceptions are created when consumers try a service.

Currently, public knowledge about SEP is more mature and more selective in using online platforms. This study uses Gojek as a sharing economy platform that is widely used by Indonesians. Value co-creation can occur because customers are willing to pay a price for convenient, economical transportation. In addition, drivers as vehicle owners are willing to drive consumers and provide fees for their services (Nadeem et al., 2019).

Consumer participation plays a very important role in the services provided by service providers, so that consumers are expected to cooperate and participate to help service providers in giving the best service to produce good and maximum cooperation values. This will increase customer satisfaction, in order that all aspects of consumer ethical perceptions can be achieved, be fulfilled, and run well. If consumers participate in achieving the goals of both parties, the value created due to cooperation will be maximized, so that the purpose of this study is to determine the effects that are given by consumer participation and ethical perceptions in the process of creating shared value.

This study needs to be done on order to fill a research gap in the role of SEP in society, especially during the COVID-19 pandemic. Research on SEP at the individual level has not received sufficient attention from academicians (Lee et al., 2018). In addition, several studies emphasized the importance of further research on the ethical side of SEP (Perren and Kozinets, 2018), because the ethical perception of SEP from the consumer side has not received much attention from academicians (Nadeem et al., 2020). Furthermore, to the best of the researchers' knowledge, the influence of ethical perceptions and consumer participation in creating value co-creation that provides value for both consumers and service providers reviewed based on Service-Dominant Logic (Vargo and Lusch, 2004) has not been given much concern by academicians, especially in Indonesia. This research model is expected to explain and strengthen the role of consumer ethical perceptions of SEP.

Based on the above background, this study will further examine the effects of consumer participation on value co-creation with ethical perceptions as a mediating variable. This research is significant because currently SEP is one of the alternatives to meet the needs of the community for various services. In addition, to the best of the researcher's knowledge, the consumer ethical perception variable is rarely discussed by academicians, especially when it comes to online business platforms. This research is expected to contribute to SEP, namely the importance of consumer participation and ethical perceptions in shaping the value co-creation of SEP users, especially during the COVID-19 pandemic. In addition, the results of this study can provide input for academicians on the use of Service Dominant Logic in SEP online in Indonesia regarding the role of consumer ethical perceptions in the relationship between consumer participation in value co-creation.

\section{THEORETICAL REVIEW}

Service-dominant Logic (SD Logic). The theory underlying this research is Servicedominant Logic (SD Logic) introduced by (Vargo and Lusch, 2008). In research conducted by (Vargo and Lusch, 2016), it is said that marketing activities (and economic activities in general) are best understood in the form of service-for-service exchanges, rather than goodsfor-goods or goods-for-money exchanges. In other words, marketing is an activity that comes from the knowledge and abilities that a person does for oneself and others (namely 
services and applied abilities). In short, the SD logic represents the dynamics of sustainable value creation through resource integration and service exchange. In this sense, consumers are always active participants and collaborative partners in exchanges, and consumers create value together with the company (Vargo and Lusch, 2008).

Consumer Participation. Consumer participation in SEP is done to achieve shared value creation through voluntary participation (Kamboj and Rahman, 2017). The definition of consumer participation according to (Chen and Chen, 2017) is the extent to which customers are involved in producing and providing services.

Based on these definitions, the definition of consumer participation used in this study is the creation of shared value through voluntary participation between recipients and service providers where consumers as service recipients are involved in producing and providing services.

Consumer participation in online SEP is defined as the extent to which online members participate actively in online platform activities, because the number of people participating in SEP determines the long-term success of an online platform (Koh and Kim, 2004). Therefore, online platforms do their best to encourage consumers to be actively involved in platforms for sustainable relationships (Algesheimer et al., 2005a).

(Kamboj and Rahman, 2017) distinguished consumer participation into three types, namely informational participation, actionable participation, and attitudinal participation. Informational participation is the extent to which consumers are interested in obtaining information and fulfilling public interests in products or services. Actionable participation refers to the extent to which consumers participate in SEP activities, and it describes the level of interactions between consumers in SEP. Attitudinal participation is related to the psychological tendency of consumers to evaluate SEP performance based on the benefits obtained by consumers or attitudes towards products/services or platforms in general (Kamboj and Rahman, 2017).

Value Co-Creation. (Vargo and Lusch, 2008) defined value co-creation as a company's efforts to rely on consumers to create shared value and company efforts to utilize consumers by using their experiences to create value through the creation and development of products or services.

(Nadeem et al., 2019) argue that value co-creation emphasizes the joint efforts of consumers and companies. This means that there are interdependencies and reciprocity that is very important to explain the interrelated roles between the production of value creation and the services it provides.

From the above definition, the definition of value co-creation used in this study is a joint effort by consumers and companies that are interrelated in creating shared value through the creation and development of products or services.

In general, value co-creation reflects a participatory culture, where consumers seek opportunities to contribute to a virtual world that allows companies to assess consumer insights about their brands (Lin et al., 2013).

In SEP, value co-creation occurs where on the one hand consumers are willing to pay a price for comfortable, economical, alternative transportation, like for taxi services. On the other hand, there are service providers (drivers) who are willing to direct customers and charge fees for the services they provide (Nadeem et al., 2019). Therefore, when the number 
of subscribers increases, SEP will attract more service providers (drivers) to join the platform and vice versa.

Consumer Ethical Perceptions. Consumer ethical perceptions are part of marketing ethics. Marketing ethics is part of business ethics and can be defined briefly as standards of behavior and moral decisions that are applied to marketing practices (Gaski, 1999). In contrast, (Laczniak and Murphy, 2014) define marketing ethics as moral standards that are applied to marketing decisions, behavior, and organizations.

The definition of consumer ethical perceptions, according to Nadeem et al. (2020), is consumers' perceptions of the responsibility and integrity of online platform companies. Meanwhile, (Teubner and Flath, 2019) defined ethical perceptions as including the privacy and security of their own personal data and also the ethical behavior of other customers. (Agag, 2018) classified consumer ethical perceptions as consumer perceptions of company behavior in dealing with consumers in a confidential, fair, honest, and sincere manner with the aim of maintaining consumer safety.

Based on the above definitions, the researcher can consider consumer ethical perceptions as the customer's point of view or perception of corporate responsibility behind the online platform in handling the privacy and security of customer personal data in a confidential, fair, honest, and sincere manner with the aim of maintaining consumer security.

In a study conducted by (Nadeem et al., 2019) regarding ethics related to SEP transactions, it is stated that the ethical aspects of offline and online businesses are different. Ethical violations are more common on online platforms than face-to-face transactions and consumer ethical evaluations differ on online and offline platforms (Roman, 2007). Online activities in general are often seen as an easy place to behave unethically (Hajli, 2018). Sharing personal information online leaves consumers vulnerable to accidental and intentional harm by other consumers.

Consumers' ethical perceptions refer to perceptions of corporate responsibility and integrity on online platforms (Nadeem et al., 2019). This is related to efforts to interact with consumers in a safe, confidential, fair, and honest manner which ultimately protects the interests of consumers (Roman, 2007). Hence, consumers' ethical perceptions about SEP include both their own personal data and the ethical behavior of other consumers and SEPs (Nadeem et al., 2019). (Algesheimer et al., 2005b) contend that online platforms try to encourage consumers as much as possible to be actively involved in the platforms for longterm relationships. However, this high level of engagement depends on consumers' positive ethical perceptions of online platforms (Roman, 2007).

Consumers' ethical perceptions are considered as a multidimensional construct consisting of six dimensions, namely: privacy, security, non-deception, fulfillment/ reliability, shared value, and service recovery (Nadeem et al., 2019). However, according to (Roman, 2007), privacy and security have consistently been identified as two major ethical issues. Therefore, the consumer ethical perception variable in this study only focuses on the dimensions of privacy and security.

The privacy dimension of consumers' ethical perceptions in SEP refers to protecting personal identifiable information from unauthorized or unwanted use by other consumers (Lutz et al., 2018). Consumer concerns about the handling of online platforms for consumer 
personal information in terms of use and subsequent disclosures are related to privacy issues (Nadeem et al., 2019).

The security dimension of consumers' ethical perceptions relates to the idea of uncertainty about online platforms that can cause monetary losses during interactions on those platforms (Roman, 2007). In SEP, the security provided refers to the security of online transactions, including protection from malware and unauthorized access to personal financial information and the security of payment methods (Nadeem et al., 2019).

\section{Relationships between Variables}

Relationship between Consumer Participation and Value Co-Creation. Based on research conducted by (Taheri et al., 2017) in the tourism and hotel industry in Iran, it shows that consumer participation has a direct positive impact on value co-creation. This is due to the participation of customers, which will create shared value between the company and customers.

Research by (Nadeem et al., 2019a) on SEP reveals that consumer participation has a positive impact and affects value co-creation. The exploratory method was used in this research. IBM SPSS Amos version 24 was applied to analyze the data.

The results of research conducted by (Chen and Wang, 2016) also show that consumer participation and value co-creation have a positive relationship. This is because without the participation of customers, shared value between the customer and the company will not be created. Therefore, consumer participation is important in influencing value co-creation. The research was conducted in the aviation industry, where visitors who had experience using the online check-in system were assigned to be the respondents, and it collected 313 respondents.

Relationship between Consumer Participation and Consumer Ethical Perceptions. Research conducted by (Nadeem et al., 2019) on the e-commerce industry and the service sector shows that consumer participation has a positive impact and affects consumers' ethical perceptions. This is because more participation in SEPs can also make customers more aware of how their data is further collected and processed by SEPs.

In research conducted by (Canas et al., 2016) in the service sector, it demonstrates that consumer participation in online platforms results in value co-creation that involves ethical products and services. This can occur because ethical values play an important role in encouraging customer participation in creating shared value. This research was a qualitative study. It utilized an observational technique to collect data and used a literature review method.

Relationship between Consumer Ethical Perceptions and Value Co-Creation. Based on research conducted by (Nadeem et al., 2019) who examined the SEP industry, consumers' ethical perceptions have a positive effect on value co-creation in SEP. This is because the better the consumers' ethical perceptions are, the higher the value of co-creation will be. This study used a survey to collect data which was conducted online for 7 days, and it collected 453 respondents.

Based on another study conducted by (Nadeem et al., 2020) who observed the SEP industry for generation $\mathrm{Y}$, the results revealed that consumer ethical perceptions have a positive and significant effect on value co-creation in SEP. The results showed that the 
intention of creating value together with customers can be greatly influenced by the ethical perceptions of customers towards the seller.

Research by (Nadeem and Al-Imamy, 2020) on the e-commerce industry and in the service sector confirmed that there is a relationship between consumer ethical perceptions and value co-creation. The results portrayed that consumer ethical perceptions of SEP can foster a positive relationship on the platform.

Research Model. Figure 1 depicts the research model that will be tested further.

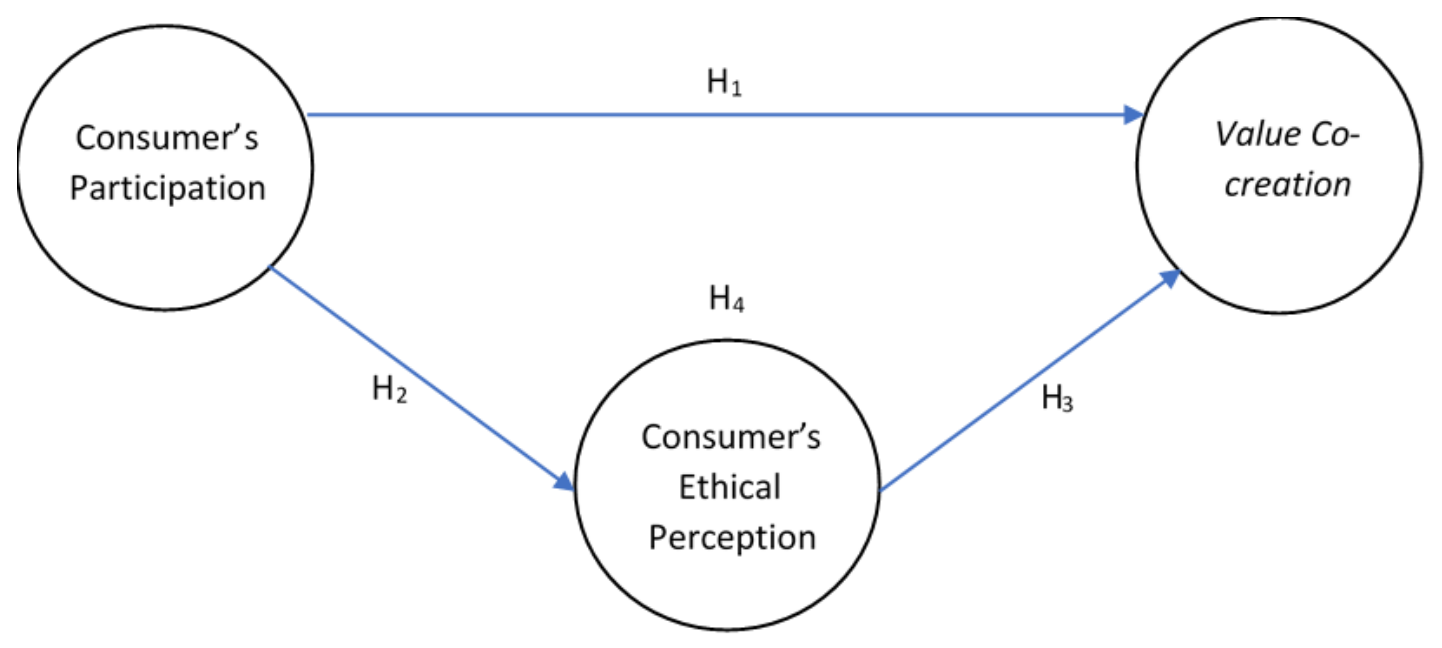

Figure 1. Research Model

The hypotheses built in this study according to the above research model are:

Hypothesis 1: Consumer participation has a significant and positive effect towards the value co-creation of SEP.

Hypothesis 2: Consumer participation has a significant and positive effect towards consumer ethical perceptions of SEP.

Hypothesis 3: Consumer ethical perceptions have a significant and positive effect towards the value co-creation of SEP.

Hypothesis 4: Consumer participation has a significant effect towards the value co-creation of SEP with consumer ethical perceptions as a mediation variable.

\section{METHODS}

This research was conducted in Jakarta with data collection in November - December of 2020. A convenience sampling technique was utilized. The detailed information about this research sample could be seen in Table 1 below. 
Table 1. Respondents' Data

\begin{tabular}{l|l|l}
\hline Item & Total & \% \\
\hline Data obtained & 341 & 100 \\
\hline Did not pass the screening questions & 28 & 8.21 \\
\hline Incomplete questionnaires & 26 & 7.62 \\
\hline \hline Usable data & 287 & 84.16 \\
\hline
\end{tabular}

This study used data from the results of filling out questionnaires by 341 respondents via Google Form. From the data collected, it turned out that 28 of them did not pass the screening questions and 26 respondents did not fill out the questionnaire completely. Therefore, the data that could be used for a further analysis came from 287 respondents, because based on the opinion of (Hair et al., 2015), the number of samples should be above 100 respondents. This study used a survey technique to collect the data with a cross sectional study. The hypothesis testing applied Smart PLS.

Table 2. Research Variable Operationalization

\begin{tabular}{|c|c|c|}
\hline Dimension & Indicator & Code \\
\hline \multicolumn{3}{|c|}{ Consumer Participation } \\
\hline \multirow{3}{*}{$\begin{array}{l}\text { Informational } \\
\text { participation }\end{array}$} & Provides information $\mathrm{X}$ & $\mathrm{CP} 1$ \\
\hline & Replies to a message in application X & $\mathrm{CP} 2$ \\
\hline & Provides feedback in application $\mathrm{X}$ & CP3 \\
\hline \multirow{3}{*}{$\begin{array}{l}\text { Attitudinal } \\
\text { participation }\end{array}$} & Participates by giving me a good influence & $\mathrm{CP} 4$ \\
\hline & Participates to be beneficial to me & CP5 \\
\hline & Participates to provide satisfaction to me & CP6 \\
\hline \multirow{2}{*}{$\begin{array}{l}\text { Actionable } \\
\text { participation }\end{array}$} & Actively participates in application $\mathrm{X}$ & CP7 \\
\hline & Spends time online to participate with SEP activities & CP8 \\
\hline \multicolumn{3}{|c|}{ Consumer Ethical Perceptions } \\
\hline \multirow[t]{4}{*}{ Privacy } & Will not use personal information & EP1 \\
\hline & Ensures the confidentiality of personal information & EP2 \\
\hline & Only uses my personal information for authentication purposes & EP3 \\
\hline & $\begin{array}{l}\text { Does not analyze a customer's consumer habits without my } \\
\text { agreement }\end{array}$ & EP4 \\
\hline \multirow[t]{4}{*}{ Security } & Has easy-to-understand security transaction policies & EP5 \\
\hline & Has a safe electronic payment system & EP6 \\
\hline & Has guidelines for doing electronic payments properly & EP7 \\
\hline & Has secure payment guidelines & EP8 \\
\hline \multicolumn{3}{|c|}{ Value Co-Creation } \\
\hline \multirow[t]{3}{*}{-} & Is willing to provide advice & $\mathrm{CC} 1$ \\
\hline & Is willing to use a service recommended by a friend & $\mathrm{CC} 2$ \\
\hline & Considers a friend's experience in using a service & $\mathrm{CC} 3$ \\
\hline
\end{tabular}

The variable operationalization of this study was entirely adopted from the research of (Nadeem et al., 2019) and used 5-point likert scale. 


\section{RESULTS}

Most of the data was from students at Tarumanagara University, Jakarta, Indonesia. The detailed demographic data could be seen below.

Table 3. Respondents' Demographic Data

\begin{tabular}{|c|c|c|}
\hline Item & Total & $\%$ \\
\hline \multicolumn{3}{|l|}{ Gender } \\
\hline Female & 147 & 51.22 \\
\hline Male & 140 & 48.78 \\
\hline \multicolumn{3}{|l|}{ Location } \\
\hline DKI Jakarta & 223 & 77.70 \\
\hline Other Provinces & 35 & 12.20 \\
\hline West Java & 28 & 9.76 \\
\hline Central Java & 1 & 0.35 \\
\hline \multicolumn{3}{|l|}{ Occupation } \\
\hline University Student & 275 & 95.82 \\
\hline Employee & 7 & 2.44 \\
\hline Other & 3 & 1.05 \\
\hline Entrepreneur & 1 & 0.35 \\
\hline Homemaker & 1 & 0.35 \\
\hline \multicolumn{3}{|l|}{ Education } \\
\hline High School & 225 & 78.40 \\
\hline Bachelor's Degree & 59 & 20.56 \\
\hline Master's Degree/ Doctorate Degree & 3 & 1.05 \\
\hline \multicolumn{3}{|l|}{ Income } \\
\hline$<\mathrm{Rp} 3,000,000$ & 221 & 77.00 \\
\hline Rp3,000,001 - Rp6,000,000 & 50 & 17.42 \\
\hline Rp6,000,001 - Rp10,000,000 & 11 & 3.83 \\
\hline$>\mathrm{Rp} 10,000,000$ & 5 & 1.74 \\
\hline
\end{tabular}

Based on the data collected from 287 respondents, 147 respondents were female (51\%), 140 respondents were male (49\%), 274 respondents were 17-22 years old (95\%), 223 respondents were domiciled in Jakarta (78\%), 225 respondents had a high school education (78\%), and 275 respondents were school/university students (96\%). The hypothesis testing was carried out using Smart PLS 3.2.

Outer Model Analysis. The outer model provides the results of testing the validity and reliability tests. In order for the indicator to be declared valid, the loading factor value must be greater than 0.50 and have a p-value of 0.000 . While the requirement for a variable to be said to be reliable is if the variable passes the internal consistency reliability test with a composite reliability value of more than 0.70 and less than 0.95 . The Cronbach's alpha test is said to be considered valid if the Cronbach's alpha value of a variable is greater than 0.6 
(Latan and Noonan, 2017). In addition, a variable is said to pass the convergent validity test if it has an Average Variance Extracted (AVE) value of more than 0.50.

In the first test results, the loading factor value for the CP2, CP8, and EP1 indicators was below 0.6. For this reason, these two indicators were excluded from further testing. The following table contains the tests carried out after the CP2, CP8, and EP1 indicators were not included in the test.

Table 4. Results of the Outer Model Analysis

\begin{tabular}{|c|c|c|c|c|c|}
\hline \multirow[t]{2}{*}{ Variable } & \multirow[t]{2}{*}{ Item } & \multicolumn{2}{|c|}{ Validity } & \multicolumn{2}{|c|}{ Reliability } \\
\hline & & $\begin{array}{l}\text { Loading } \\
\text { Factor }\end{array}$ & AVE & $\begin{array}{l}\text { Cronbach's } \\
\text { Alpha }\end{array}$ & CR \\
\hline \multirow{6}{*}{$\begin{array}{l}\text { Consumer } \\
\text { Participation }\end{array}$} & CP1 & 0.627 & \multirow{6}{*}{0.539} & \multirow{6}{*}{0.824} & \multirow{6}{*}{0.873} \\
\hline & CP3 & 0.683 & & & \\
\hline & CP4 & 0.829 & & & \\
\hline & CP5 & 0.823 & & & \\
\hline & CP6 & 0.786 & & & \\
\hline & CP7 & 0.624 & & & \\
\hline \multirow{6}{*}{$\begin{array}{l}\text { Ethical } \\
\text { Perception }\end{array}$} & EP2 & 0.789 & \multirow{6}{*}{0.600} & \multirow{6}{*}{0.865} & \multirow{6}{*}{0.900} \\
\hline & EP3 & 0.833 & & & \\
\hline & EP4 & 0.683 & & & \\
\hline & EP5 & 0.718 & & & \\
\hline & EP6 & 0.817 & & & \\
\hline & EP7 & 0.797 & & & \\
\hline \multirow{3}{*}{$\begin{array}{l}\text { Value } \\
\text { Creation }\end{array}$} & CC1 & 0.833 & \multirow{3}{*}{0.677} & \multirow{3}{*}{0.762} & \multirow{3}{*}{0.863} \\
\hline & $\mathrm{CC2}$ & 0.829 & & & \\
\hline & CC3 & 0.806 & & & \\
\hline
\end{tabular}

A variable is called passing the discriminant validity test if the Heterotrait-Monotrait Ratio (HTMT) value is less than 0.90 and the Fornell-Larcker Criterion Test value, namely the value of the square root AVE of each variable is greater than the value of the coefficient of determination $\left(\mathrm{R}^{2}\right)$ of the variable with other variables. In Table 5 , it can be seen that all variables have passed the discriminant validity test. 
Table 5. Results of the Discriminant Validity Analysis

Fornell-Larcker Criterion

\begin{tabular}{l|r|r|r}
\hline & CP & EP & \multicolumn{2}{|c}{ VCC } \\
\hline CP & 0.734 & & \\
\hline EP & 0.448 & 0.775 & 0.823 \\
\hline VCC & 0.579 & 0.578 & \\
\hline & & & \\
\hline
\end{tabular}

\begin{tabular}{l|l|c|c}
\multicolumn{5}{c}{ HTMT } & VCC \\
\hline CP & CP & EP & \\
\hline EP & & & \\
\hline VCC & 0.524 & 0.706 & \\
\hline
\end{tabular}

Inner Model Analysis. An inner model analysis is conducted to determine the relationships between variables. The R-Square value is used to measure the level of variation in the change in the independent variable on the dependent variable. The $\mathrm{R}^{2}$ criteria consists of three classifications, namely the $\mathrm{R}^{2}$ values of $0.67,0.33$, and 0.19 as strong, moderate, and weak. Changes in the value of $\mathrm{R}^{2}$ can be used to see whether the effects of the exogenous latent variables on the endogenous latent variables have a substantive effect.

Table 6. $\mathrm{R}^{2}$ Test Results

\begin{tabular}{l|ll}
\hline & R Square & \\
\hline EP & & 0.201 \\
\hline VCC & & 0.462 \\
\hline
\end{tabular}

Based on Table 6 above, the consumer participation variable has a moderate prediction of 0.462 on value co-creation. This means that if there is a change in the consumer participation variable, then the value co-creation variable also changes by $46.2 \%$ and the remaining $53.8 \%$ is influenced by other variables. The consumer participation variable has a weak prediction of 0.201 on ethical perceptions.

Table 7. F-Test Results

\begin{tabular}{l|l|l|l}
\hline & $\mathbf{C P}$ & $\mathbf{E P}$ & VCC \\
\hline $\mathbf{C P}$ & & 0.252 & 0.238 \\
\hline $\mathbf{E P}$ & & & 0.236 \\
\hline $\mathbf{V C C}$ & & & \\
\hline
\end{tabular}

The effect size $\mathrm{f}^{2}$ was used to evaluate whether the predictor constructs if omitted would have a major impact on the f-Square values of the endogenous constructs. Based on Table 7, the relationship of each variable has a moderate effect. 
Hypothesis Testing. The hypothesis testing in this study was divided into two parts, namely testing the influence of the hypothesis and the direct relationship to test $\mathrm{H}_{1}, \mathrm{H}_{2}$, and $\mathrm{H}_{3}$. In addition, the effects of the hypothesis and the indirect relationships (through the mediator variable) were examined to test $\mathrm{H} 4$. In order for the hypothesis to be accepted, the t-statistic value should have a significance level of $95 \%$, which is more than 1.96 , and a p-value of less than 0.05 .

A path coefficient test was performed to show the magnitude of the influence of the independent variable on the dependent variable. This value also shows how much of an increase or decrease there is in the dependent variable for every 1 unit increase in the independent variable (Latan and Noonan, 2017). The relationship that can be shown from the path coefficient value is from -1 to +1 . The direction shown by a negative or positive sign is the relationship between the related variables.

A mediation analysis in a research model in PLS-SEM can be done by looking at the value of the indirect effect of the research model (independent variable $\rightarrow$ mediating variable $\rightarrow$ dependent variable). The mediation variable is stated to be able to mediate if the indirect effect value of the mediation relationship is greater than the significance value (tstatistics $>1.96 ; \alpha=5 \%$ ), and if the indirect effect value shows insignificance, then the variable is declared unable to mediate in the research model (Nitzl et al., 2016).

The bootstrap method can be used for various things, one of which is to determine the t-statistic value as is done in the Partial Least Square SEM model. With the bootstrap method or resampling up to 5000 times, the standard deviation value can be calculated so that the $\mathrm{t}$ statistic value can be calculated by dividing the regression coefficient by the standard deviation. The significance test is carried out to determine the significance of direct and indirect effects, where the requirements for t-statistics must be greater than the t-value. The $\mathrm{t}$-value used is 1.645 (Hair et al., 2011).

(Nitzl et al., 2016) stated that the mediation effect that arises in the research model can be categorized as a type of full mediation, partial mediation, or no mediation, but there are only significant direct effects.

The mediation variable (M) can be expressed as full mediation in a research model if the value of the indirect effect (independent variable $\rightarrow$ mediating variable $\rightarrow$ dependent variable) shows a significant result with a t-statistical value greater than 1.96 at $\alpha=5 \%$; however, the relationship of the independent variable $(\mathrm{X})$ to the dependent variable $(\mathrm{Y})$ has an insignificant value.

The mediation variable $(\mathrm{M})$ is stated as partial mediation in the research model of the value of the indirect effect (independent variable $\rightarrow$ mediating variable $\rightarrow$ dependent variable) shows a significant result (t-statistics $>1.96 ; \alpha=5 \%$ ), and the prediction of the independent variable $(\mathrm{X})$ to the dependent variable $(\mathrm{Y})$ also has a significant value.

Table 8 below describes the results of the path coefficient, t-statistics, and p-values derived from the output of the smart PLS obtained. 
Table 8. Path Coefficient, t-Statistic, and p-Value Analysis Results

\begin{tabular}{c|l|r|r|r|c}
\hline & \multicolumn{1}{|c|}{ Variable Relationship } & $\begin{array}{c}\text { Path } \\
\text { Coefficient }\end{array}$ & t-Statistic & p-Value & Results \\
\hline 1 & $\begin{array}{l}\text { Consumer Participation } \rightarrow \text { Value } \\
\text { Co-Creation }\end{array}$ & 0.400 & 7.424 & 0.000 & Supported \\
\hline 2 & $\begin{array}{l}\text { Consumer Participation } \rightarrow \text { Ethical } \\
\text { Perception }\end{array}$ & 0.448 & 9.022 & 0.000 & Supported \\
\hline 3 & $\begin{array}{l}\text { Ethical Perception } \rightarrow \text { Value Co- } \\
\text { Creation }\end{array}$ & 0.399 & 7.426 & 0.000 & Supported \\
\hline 4 & $\begin{array}{l}\text { Consumer Participation - Ethical } \\
\text { Perception - Value Co-Creation }\end{array}$ & 0.179 & 6.080 & 0.000 & Supported \\
\hline
\end{tabular}

From the table, the path coefficient value for $\mathrm{H}_{1}$ is 0.400 , where the value is greater than zero. The t-statistics value for $\mathrm{H} 1$ is 7.424 , where this value is greater than 1.96 . The p-value for $\mathrm{H}_{1}$ is 0.000 , where the value is less than 0.05 with a confidence level of $95 \%$. Based on the path coefficient, $\mathrm{t}$-statistics and, $\mathrm{p}$-value, $\mathrm{H}_{1}$ is accepted and it can be concluded that consumer participation has a significant effect on value co-creation and the two variables have a positive relationship.

The path coefficient value for $\mathrm{H}_{2}$ is 0.448 , where the value is greater than zero. The tstatistics value for $\mathrm{H} 2$ is 9.022 , where this value is greater than 1.96. The p-value for $\mathrm{H}_{2}$ is 0.000 , which is less than 0.05 with a confidence level of $95 \%$. Based on the path coefficient, t-statistics, and p-value, $\mathrm{H}_{2}$ is accepted. Therefore, it can be concluded that consumer participation has a significant effect on ethical perceptions and the two variables have a positive relationship.

The path coefficient value for $\mathrm{H}_{3}$ is 0.399 , where the value is greater than zero. The $\mathrm{t}-$ statistics value for $\mathrm{H}_{3}$ is 7.426 , where this value is greater than 1.96. The p-value for $\mathrm{H}_{3}$ is 0.000 , where the value is less than 0.05 and the confidence level is $95 \%$. Based on the value of the path coefficient, t-statistics and, p-value, $\mathrm{H}_{3}$ is accepted. So, it can be concluded that ethical perceptions have a significant effect on value co-creation, and the two variables have a positive relationship.

The path coefficient value for $\mathrm{H}_{4}$ is 0.179 , where the value is greater than zero. The $\mathrm{t}$ statistics value for $\mathrm{H} 4$ is 6.080 , where this value is greater than 1.96. The p-value for $\mathrm{H}_{4}$ is 0.000 , which is less than 0.05. Based on the t-statistics, p-value, and path coefficient, $\mathrm{H}_{4}$ is accepted. Consequently, it can be concluded that ethical perceptions as a mediating variable have a significant effect on partially mediating consumer participation and value cocreation, and the mediation relationship has a positive direction.

Based on the results of the analysis above, a summary of the test results for each hypothesis can be made below: 
Table 9. Summary of the Hypothesis Test Results

\begin{tabular}{l|l|c}
\hline & \multicolumn{1}{|c}{ Hypothesis } & Results \\
\hline $\mathrm{H}_{1}$ & $\begin{array}{l}\text { Consumer participation has a significant and positive effect on the value } \\
\text { co-creation of SEP. }\end{array}$ & Supported \\
\hline $\mathrm{H}_{2}$ & $\begin{array}{l}\text { Consumer participation has a significant and positive effect on the } \\
\text { consumer ethical perceptions of SEP. }\end{array}$ & Supported \\
\hline $\mathrm{H}_{3}$ & $\begin{array}{l}\text { Consumer ethical perceptions have a significant and positive effect on the } \\
\text { value co-creation of SEP. }\end{array}$ & Supported \\
\hline $\mathrm{H}_{4}$ & $\begin{array}{l}\text { Consumer participation has a significant effect on the value co-creation of } \\
\text { SEP with consumer ethical perceptions as a mediating variable. }\end{array}$ & Supported \\
\hline
\end{tabular}

\section{DISCUSSION}

This research refers to the theory of Service Dominant Logic (SD Logic). This theory focuses on operational resources, namely resources that act on or produce other resources, and are also the main resources needed by companies, because this type includes human, organizational, informational, and relational resources (Dakael, 2009).

Based on the validity test of the indicators, the results show that in the consumer participation variable there are two indicators that have a loading factor value below 0.6. This indicator discusses informational participation, namely replying to messages on the SEP application and actionable participation, especially on consumer interest in spending time participating in SEP activities. This is likely due to the conditions of the COVID-19 pandemic, so that the space for the community is more limited due to the large-scale social restrictions set by the government. In addition, there is one indicator in the consumer ethical perception variable that discusses consumer privacy, which is the statement that the company will not use personal information with a loading factor value below 0.6 . This is probably due to the public awareness that the company will still use consumers' personal information for authentication purposes and consumers have high hopes that the company will guarantee the confidentiality of this information.

In the $\mathrm{H}_{1}$ test, it shows that $\mathrm{H}_{1}$ is accepted. So, it can be concluded that consumer participation has a significant effect on value co-creation, and the two variables have a moderate relationship with a positive direction. The results of this study are in accordance with research conducted by (Taheri et al., 2017), which states that consumer participation has an influence on value co-creation. These results reinforce the understanding that informational, attitudinal, and actionable participation of consumers can have a positive and significant influence on value co-creation from consumer perceptions.

Hypothesis testing results of $\mathrm{H}_{2}$ reveals that $\mathrm{H}_{2}$ is accepted. Therefore, it can be concluded that consumer participation has a significant effect on ethical perceptions, and the two variables have a positive and strong relationship. The results of this study are consistent with research conducted by (Nadeem et al., 2019), which states that consumer participation has a positive effect on ethical perceptions. Furthermore, the results of this study indicate that the influence of consumer participation on ethical perceptions is the strongest compared to the relationships of other variables. These results reinforce the results of previous research that informational, attitudinal, and actionable participation of consumers can have a positive influence on the ethical perceptions of consumers in terms of privacy and security. 
Results of $\mathrm{H}_{3}$ test discloses that $\mathrm{H}_{3}$ is accepted. So, it can be concluded that ethical perceptions have a significant effect on value co-creation, and the two variables have a positive and moderate relationship. The results of this study are consistent with research conducted by (Nadeem et al., 2019), which discovered that ethical perceptions have a significant effect on value co-creation.

In the $\mathrm{H}_{4}$ test, it shows that $\mathrm{H}_{4}$ is accepted. As a result, it can be surmised that ethical perceptions as a mediating variable have a significant effect in partially mediating consumer participation and value co-creation, and the mediation relationship has a positive direction. The results of this study are consistent with research conducted by (Nadeem et al., 2019), which states that ethical perceptions as a mediating variable have a significant effect on mediating consumer participation and value co-creation.

\section{CONCLUSION}

Based on the results of the tests that were carried out, it was found that consumer participation in SEP has a significant effect on ethical perceptions, and value co-creation has a significant and positive effect. In addition, ethical perceptions as a mediator variable have a significant effect on partially mediating consumer participation and value co-creation in SEP, and the mediation relationship has a positive direction.

From the results of the questionnaires distributed, it was discovered that regarding consumer participation, the consumers felt that actively participating in SEP would have a positive effect and was considered as being beneficial for consumers. In addition, the ethical perceptions applied by the SEP firms have received considerable attention from consumers, where some consumers agree that personal information should only be used for authentication purposes and not for other reasons. Consumers also hope that companies can maintain the confidentiality of data that consumers provide to the firms.

Furthermore, this research shows that consumers' intention to coordinate with the company is highly valued by consumers, where some consumers are apparently willing to provide advice to the company, consider the experiences of knowledgeable people in using services, and place more trust in services that receive recommendations from people they know.

The results of this study can fill the research gap on the ethical perceptions of SEP consumers. The research model provided can be a platform for conducting further broad studies. This can provide input for academicians in the form of evidence that supports similar previous studies, especially with regard to the SEP industry which has become an interesting phenomenon in this decade, especially during the COVID-19 pandemic. In addition, this study uses Service Dominant Logic (Vargo and Lusch, 2008) as the theoretical basis. This could expand the use of Service Dominant Logic to the relatively new SEP industry. With this research, it is hoped that it can add to the robustness of the theory in the world of marketing, so that the theory can become a basis for broader research.

Research Limitations And Suggestions. This study only used a limited sample of one SEP provider in Indonesia with a limited number of respondents. For future research, more samples can be obtained from SEP users with a wider coverage to get the robustness of the research results. 
In addition, this study only applied two dimensions of the six dimensions of marketing ethics perceptions. Researchers can then explore the use of four other dimensions, namely non-deception, fulfillment/reliability, shared value, and service recovery (Nadeem et al., 2019) to expand on similar research.

This research model only tested three variables related to SEP, namely value cocreation, consumer ethical perceptions, and consumer participation in relation to the Service Dominant Logic theory. Future research can use other variables related to Service Dominant Logic. In addition, other researchers can extend the research with respondents who come from other regions or different countries. Academicians can also expand the research by using service providers as respondents. This will add to the robustness of the use of the Service Dominant Logic theory in the marketing realm.

For academicians, research on SEP is still an interesting area for further research, involving a variety of different variables. Research using other variables related to SEP marketing will enrich research on this SEP.

This study provides input for practitioners, especially SEP practitioners, to pay attention to the importance of customer participation in sharing economic platforms to create shared value, where the results of this study indicate that the results are significant and positive. In addition, consumer perceptions of the ethics of the Sharing Economic Platform service need to get more attention by SEP companies, as the intention of creating shared value by customers can be greatly influenced by the customer's ethical perception of this service provider. Furthermore, SEP practitioners should pay attention to the importance of consumer participation in relation to consumer ethical perceptions because the results of this study show the greatest coefficient value in this relationship.

\section{REFERENCES}

Agag, G. (2018). E-commerce ethics and its impact on buyer repurchase intentions and loyalty: An empirical study of small and medium Egyptian businesses. Journal of Business Ethics. https://doi.org/10.1007/s10551-017-3452-3.

Algesheimer, R., Dholakia, U. M., and Herrmann, A. (2005). The social influence of brand community: Evidence from European car clubs. Journal of Marketing, 69(3), 19-34. https://doi.org/10.1509/jmkg.69.3.19.66363.

Chen, C. C. V., and Chen, C. J. (2017). The role of customer participation for enhancing repurchase intention. Management Decision. https://doi.org/10.1108/MD-06-20160380 .

Dillahunt, T. R., and Malone, A. R. (2015). The promise of the sharing economy among disadvantaged communities. Conference on Human Factors in Computing Systems Proceedings. https://doi.org/10.1145/2702123.2702189.

Gaski, J. F. (1999). On interorganizational dependence and social power: A follow-up of Zemanek and McIntyre. Psychological Reports. https://doi.org/10.2466/pr0.85.5.323326.

Hair, Jr, J. F. (2015). Essentials of business research methods. In Essentials of Business Research Methods. https://doi.org/10.4324/9781315704562.

Hajli, N. (2018). Ethical environment in the online communities by information credibility: A social media perspective. Journal of Business Ethics, 149(4), 799-810. https://doi.org/10.1007/s10551-016-3036-7. 
Kamboj, S., and Rahman, Z. (2017). Measuring customer social participation in online travel communities: Scale development and validation. Journal of Hospitality and Tourism Technology, 8(3), 432-464. https://doi.org/10.1108/JHTT-08-2016-0041.

Koh, J., and Kim, Y.-G. (2004). Knowledge sharing in virtual communities: An e-business perspective. https://doi.org/10.1016/S0957-4174(03)00116-7.

Laczniak, G. R., and Murphy, P. E. (2014). The relationship between marketing ethics and corporate social responsibility: Serving stakeholders and the common good. Handbook of Research on Marketing and Corporate Social Responsibility, 68-87. https://doi.org/10.4337/9781783476091.00009.

Latan, H., and Noonan, R. (2017). Partial least squares path modeling: Basic concepts, methodological issues and applications. In Partial Least Squares Path Modeling: Basic Concepts, Methodological Issues and Applications. Springer International Publishing. https://doi.org/10.1007/978-3-319-64069-3.

Lee, Zach W. Y., Chan, Tommy K. H., Balaji, M. S. and Alain Yee-Loong, Chong (2018) Why People Participate in the Sharing Economy: An Empirical Investigation of Uber. Internet Research, 28 (3). 829-850. ISSN 1066-2243. https://doi.org/10.1108/IntR01-2017-0037.

Lin, M. J. J., Tu, Y. C., Chen, D. C., and Huang, C. H. (2013). Customer participation and new product development outcomes: The moderating role of product innovativeness. Journal of Management and Organization. https://doi.org/10.1017/jmo.2013.8.

Lutz, C., Hoffmann, C. P., Bucher, E., and Fieseler, C. (2018). The role of privacy concerns in the sharing economy. Information Communication and Society, 21(10), 1472-1492. https://doi.org/10.1080/1369118X.2017.1339726.

Mittendorf, C. (2016). What trust means in the sharing economy: A provider perspective on Airbnb.com. AMCIS 2016: Surfing the IT Innovation Wave - 22nd Americas Conference on Information Systems.

Nadeem, W., and Al-Imamy, S. (2020). Do ethics drive value co-creation on digital sharing economy platforms? Journal of Retailing and Consumer Services. https://doi.org/10.1016/j.jretconser.2020.102095.

Nadeem, W., Juntunen, M., Hajli, N., and Tajvidi, M. (2019). The role of ethical perceptions in consumers' participation and value co-creation on sharing economy platforms. Journal of Business Ethics. https://doi.org/10.1007/s10551-019-04314-5.

Nadeem, W., Juntunen, M., Shirazi, F., and Hajli, N. (2020). Consumers' value co-creation in sharing economy: The role of social support, consumers' ethical perceptions, and relationship quality. Technological Forecasting and Social Change, 151, 119786. https://doi.org/10.1016/j.techfore.2019.119786.

Perren, R., and Kozinets, R. V. (2018). Lateral exchange markets: How social platforms operate in a networked economy. Journal of Marketing, 82(1), 20-36. https://doi.org/10.1509/jm.14.0250.

Roman, S. (2007). The ethics of online retailing: A scale development and validation from the consumers' perspective. Journal of Business Ethics. https://doi.org/10.1007/s10551-006-9161-y.

Teubner, T., and Flath, C. M. (2019). Privacy in the sharing economy. Journal of the Association for Information Systems. https://doi.org/10.17705/1jais.00534.

Vargo, S. L., and Lusch, R. F. (2004). Evolving to a new dominant logic for marketing. Journal of Marketing, 68(1), 1-17. https://doi.org/10.1509/jmkg.68.1.1.24036. 
Vargo, S. L., and Lusch, R. F. (2008). Service-dominant logic: Continuing the evolution. Journal of the Academy of Marketing Science. https://doi.org/10.1007/s11747-0070069-6.

Vargo, S. L., and Lusch, R. F. (2016). Institutions and axioms: An extension and update of service-dominant logic. Journal of the Academy of Marketing Science. https://doi.org/10.1007/s11747-015-0456-3.

Wagner, I. (2020, Oct 19). Ride-sharing market size worldwide - outlook 2020-2021. https://www.statista.com/statistics/1155981/ride-sharing-market-size-worldwide/.

Yuni Astutik. (2020, March 17). 21,7 Juta masyarakat Indonesia pakai transportasi online. https://www.cnbcindonesia.com/tech/20200317150135-37-145529/217-jutamasyarakat-indonesia-pakai-transportasi-online.

\section{ACKNOWLEDGEMENTS}

Thank you to Tarumanagara University Research and Community Engagement (LPPM Untar) for supporting this research. 